\title{
The Oldenburg Model of Vocational Education and Training for Sustainable Development. Design within the Model Test "Advanced Training to Become a Renewable Energies/Energy Efficiency Specialist (German Chamber of Crafts)"
}

\author{
Karin Rebmann ${ }^{1}$, Tobias Schlömer ${ }^{2}$, Daniel Feldkamp ${ }^{2}$, Heike Jahncke ${ }^{1} \&$ Christina Lüllau ${ }^{1}$ \\ ${ }^{1}$ Fachgebiet Berufs- und Wirtschaftspädagogik, Carl von Ossietzky Universität Oldenburg, Oldenburg, Germany \\ ${ }^{2}$ Berufs- und Arbeitspädagogik' Helmut-Schmidt-Universität, Hamburg, Germany \\ Correspondence: Karin Rebmann, Fachgebiet Berufs- und Wirtschaftspädagogik, Carl von Ossietzky Universität \\ Oldenburg, Postfach 2503, 26111 Oldenburg, Germany. Tel: 441-798-4130. E-mail: \\ karin.rebmann@uni-oldenburg.de
}

Received: April 11, 2016

doi:10.5539/jsd.v10n3p1

\begin{abstract}
This article presents the results of a three-year (Nov. 2010-Dec. 2013) model test that was part of the "Occupational Training for a Sustainable Development" program sponsored by the German Bundesinstitut für Berufsbildung (Federal Institute for Vocational Education and Training). It was conducted by the University of Oldenburg's department of vocational training and business education jointly with the Bundestechnologiezentrum für Elektro- und Informationstechnik e. V. (BFE) (Federal Center for Electrical Engineering and Information Technology). The model test pursued two different, albeit connected research approaches: a concept-development and a theory-modelling approach. The first one successfully developed, implemented and evaluated the unique, flexible and modularized renewable energies/energy efficiency specialist advanced training as defined by $\S 42 \mathrm{a}$ of the German Chamber of Crafts' trade and crafts code. The second stream of theory-modelling complemented this by gaining well-founded insight that helps to describe and explain how exactly an occupational training works for sustainable development in professions operating in the energy sector.
\end{abstract}

Keywords: career development training, evaluation, sustainability, energy business

\section{Introduction}

The following will present the results of a three-year (November 2010-December 2013) Oldenburg model test that was part of the "Occupational Training for a Sustainable Development" funding program sponsored by the German Bundesinstituts für Berufsbildung (Federal Institute for Vocational Education and Training) and conducted by the University of Oldenburg's department of professional and economic education together with the Bundestechnologiezentrum für Elektro- und Informationstechnik e. V. (BFE) (Federal Center for Electrical Engineering and Information Technology, referred to as "BFE" in the following). The model test pursued two different, albeit connected research approaches: a concept-development and a theory-modelling approach.

The concept-development approach achieved the development, implementation, and evaluation of the renewable energies/energy efficiency specialist advanced training as defined by $\$ 42 \mathrm{a}$ of the German Chamber of Crafts' trade and crafts code. This training provides a qualification that is below the German Meisterfortbildung and thus corresponds to level five of the German Qualification Framework for Lifelong Learning (Arbeitskreis Deutscher Qualifikationsrahmen, 2011, p. 6). Although primarily geared towards technicians from the field of electrical engineering, as well as sanitary engineering, heating, and air conditioning, it also aims to reach those occupied in related professions and industries. Taking this training's exam requires the participant to have already completed a professional training and have at least two years of professional working experience.

The modular advanced training concept described in the following prepares its participants to be co-creators of the future energy economy while at the same time managing the multitude of interfaces that will be encountered in this process; all amidst a complex energy economy value network (Feldkamp et al., 2012, p. 112 f.). Here, the 
traditional forms of electricity and heat generation in central power plants are increasingly being replaced by a decentralized energy production using a variety of facilities, and where energy is distributed via intelligent networks that aim to effectively achieve an integration of all consumers. This means that energy production, usage, storage, and distribution are no longer in the sole hands of large power companies and their plants. These technological changes and developments will also see the involvement of industrial producers of modern energy technologies, trade enterprises, engineering and planning offices, and a wide array of energy service providers (particularly those in the SME realm). And recent years have seen rapidly growing investments in renewable energies, with a nearly three-fold increase in Germany between the years 2004 (6.8 billion euros) to 2011 (20.3 billion euros) (BMU, 2012, p. 18).

This growing technological complexity is expected to be accompanied by a strong growth in the market for energy trade (for more see BDI, 2008; Bitkom \& Fraunhofer ISI, 2012). Here, businesses and households will no longer only be seen as consumers, purchasers, or even storers of energy (using e.g. electric cars or refrigerators), but will also be actual participants on the market who will actively steer and define their consumption and usage on an as-needed basis. Energy production via renewable technologies will mean that weather conditions (both favorable and unfavorable) will play a much greater role in its creation and consumption, making energy a much more market-reliant good and correspondingly intensifying the market processes coordinating the interactions between producers and consumers. The necessary marketplaces and technical regulations will in the future be mostly internet-based, and even today, the market talks of an "internet of energy."

A complex system of countless interrelations emerges under these circumstances for companies operating in the energy economy. These will be facing challenges in the realm of energy technology-, market-, information-, and communication technology-related factors accompanying these changes to the energy economy. The Oldenburg advanced training curriculum therefore features instruction on commercial aspects of the energy economy, as well as energy technology itself as it achieves a connection between company service and commercial-operational management. The curriculum includes both mandatory and elective modules that allow students a custom-fit series of instruction corresponding to their professional backgrounds and the form of renewable energy they are particularly interested in. The advanced training comprises a total of 412 hours lasting around eleven months, 300 of which are in-classroom training. The mix of different professions participating in this program achieves a wide variety of learners from all kinds of professional backgrounds. Some of the students who have taken part in the program so far come from the conventional electrical trade and power supply fields, and are complemented by those from the professions of energy trade, energy sales, as well as other energy service sectors such as system support and security inspections. There have even been students from energy industry investment and financial management companies and projects.

The theory-modelling approach pursued in the model test generated effective statements that help describe and explain exactly how an occupational training works for a sustainable development in professions operating in the energy economy. From a functional perspective, the advanced training combines the challenges of creating the new energy economy within business models, action fields, and business processes on the one hand with the opportunities and necessities of developing individual career and professional competencies in the future energy economy on the other. The transformation of the energy economy promises companies new, well-paying business opportunities that require them to have well-educated, competent employees and trainees. When looking at current qualifications, the existing personnel and training infrastructures within companies may not be sufficient (at least content-wise) to prepare them for the coming changes. From a professional and economical education perspective, the existing professional training currently being offered provides insufficient opportunities for learners to successfully achieve the professional qualifications they will need in tomorrow's energy economy. And from a competency-theoretical perspective, there is a discrepancy between competency as an individual potential for formation and action and performance as something characterizing and even challenging professional formation and action.

This discrepancy was addressed in the first part of the model test via a comprehensive empirical survey using a qualitative-quantitative research design that examined the job profiles, competency requirements, professional backgrounds, and practicable education strategies and course offerings needed for an occupational training for a sustainable energy economy. Along with the theory modelling that is based on previous work done by the team conducting the study, these findings served as the foundation for the development of the advanced training.

The key concept development and theoretical outcomes of the model test results will be discussed in the following. However, before doing this the foundational assumptions of the project will be described. These are the result of previous projects and studies conducted by the authors in the field of occupational training for a sustainable development, and will be consolidated into a reference model for professional action and 
competencies for sustainable economic activity. The model test design will also be presented below.

\section{Occupational Training for a Sustainable Development: Between the Formation of Business Models and the Development of Individual Competencies}

\subsection{Paradigm Shift: From Professional Environmental Education to Occupational Training for a Sustainable Development}

The field of occupational training for a sustainable development was established at the start of the past decade at the University of Oldenburg's department of professional and economic education as a comprehensive research and developmental program. It has continued to develop via a wide array of research projects, qualification papers and studies. A key event in transitioning from the professional environmental education of the 1980s and 1990s to occupational training for a sustainable development was the project conducted by the department of professional and economic education from January of 2001 to December 2004 (and sponsored by the Deutsche Bundesstiftung Umwelt (German Federal Environmental Foundation)) on environmental communication and employee qualification in the energy supply of small- and medium-sized enterprises (Kastrup et al., 2006). This project not only produced concrete, directly applicable results (qualification building blocks, learning environments, company analyses), but future developmental approaches for occupational training for a sustainable development as well. Here it became clear that when implementing environmental regulations and requirements, and at the same time establishing ecological habits such as sorting trash, recycling, and resource efficiency, a closely conducted qualification of trainees and employees is no longer sufficient to meet the challenges of a sustainable professional, work, and company development. Instead, occupational training should provide learners vocational preparation, internships, and advanced training that lead to a comprehensive development of competencies; open pathways for future-oriented professional opportunities in environmental lead markets; and offer a sufficient amount of freedom in professional organizations. In other words, individuals should be incorporated into a result-based co-creation of strategies, goals, and actions aiming at sustainable economics.

Sustainable economics means that companies accept their industry-specific social and ecological challenges and issues in an effort to measurably achieve a responsible interaction with society, the environment, and the economy that keeps in mind the obligation to future generations, all while developing these areas into strategic market and competitive factors (for more, see Dyllick, 2003; Schaltegger \& Hasenmüller, 2006). Socially and ecologically responsible company activity here becomes a central element of company business models. It manifests itself in the development of sustainable business fields with the corresponding product and service portfolios, technical innovation for a resource- and energy-efficient production and service, or even comprehensive programs for corporate social responsibility.

These corporate activities are characterized by strong complexity. They are openly formed, and highly dynamic. Social, ecological, and economic developments are embedded within internetworked systems (the sustainability principle), are difficult to predict, and are very volatile, which can be seen (among other places) with start-up companies operating in sustainability industry niches (Leleux, 2011; Volkmann, Tokarski \& Ernst, 2012). With this being the case, sustainably operating organizations, markets, and value chains are reliant most notably on the competence and co-creation of their participating individuals. So when it comes to occupational training, the paradigm shift from a company environmental policy with its rigid procedures to a corporate sustainability management with dynamic creation tasks brings extensive consequences with it. Proper environmental behavior is no longer something static to check off the "to do" list. Now, occupational training should aim at the professional action of open, complex co-creation of sustainable economics that sensitizes, enables, and commits employees to play an essential role on their own initiative (Rebmann \& Schlömer, 2010).

\subsection{Reference Model for Professional Action and Competencies for Sustainable Economics}

Occupational training for a sustainable development brings with it the challenge of interconnecting the competency development of professionally active individuals with the relevant professional fields found in companies who sustainably operate. From a learning-theoretical point of view, this means connecting individual learning processes in the workplace with the organizational learning processes found within the companies themselves. A study by Schlömer (2009) constructed this connection into a reference model for professional action and competencies for sustainable economics.

This model takes Chomsky's (1970) differentiation between competence and performance as its basis. Competency is here understood as a cognitive construct that can produce a contingent behavior (performance), but that is not identical to it (Klieme \& Hartig, 2007). This is an important assumption for the pedagogical formation of learning processes: It means that "the existence of competence does not automatically mean that it 
is correspondingly being applied and implemented" (Gillen \& Kaufhold, 2005, p. 367). Competence is an individual potential whose varying applicability is decided on by the learners themselves. This assumption can also be found in Weinert's $(2001$, p. 27) often-cited definition stating that competencies are "the cognitive abilities and skills that are available to or learnable by individuals to solve certain problems. They also include the associated motivational, volitional, and social willingness and abilities to successfully and responsibly apply these problem solutions in variable situations."

Four key questions will be addressed, both theory-driven and empirically-explorative, based on this differentiation between performance and competence (in the following, see Schlömer, 2009, p. 7; 2010, p. 2). First, it will be clarified for which professional business models and/or performances of sustainable economics an occupational training should develop competencies. These occupational performances will then be differentiated into professional fields of action. In this study, this is realized following a social-theoretical background in accordance with the question of which (co-)formation opportunities for sustainable economics result for those who are professionally active. In connection with this, it will then be discussed from a constructivist learning theory which specific course offerings could be effective and supportive in the action and creation areas being examined. This will be concluded with a general as well as an employee-/industry-specific modelling of the competencies occupational training should aim at in its effort to achieve sustainable economics.

A constructive interconnection between performance and competence in occupational training for a sustainable development is created as the four key questions are discussed and examined. This discussion is based on systemic-constructivist theoretical assumptions (for more, see Schlömer, 2009, p. 47 ff.). Here, companies are seen as social systems in line with Hejl's (1996) theory of social action where social systems emerge when single actions by individuals are based on meaning allocations (Sinnzuweisungen) and these actions are connected to a specific meaning (in the following, see Klemisch, Schlömer \& Tenfelde, 2008; Rebmann, Tenfelde \& Schlömer, 2011, p. 88 ff.). Common meanings are socially determined via communication and action, and the point of action(s) can be based e.g. on the establishment of a common, agreed-upon understanding of what sustainable economics specifically encompasses. This is how social systems emerge whose members relate actions to one another, evaluating them using the agreed-upon criteria of meaning. From this, a difference can be determined between useful actions and those that are valid only outside of the system and that should be allocated to the realm surrounding (i.e. outside of) the system. Within this conception of social systems, individuals are understood as system components who can meaningfully correlate their constructions, i.e. their ideas, knowledge, attitudes, and beliefs about sustainable economics to one another.

The theoretically modelled statements on professional action and competence for sustainable economics will be examined and validated using a complex industrial-enterprise case study. Its empirical explorations involve multiple-step qualitative interviews and document analyses to achieve a differentiation and precise localization of both theoretically- and empirically-founded model dimensions. The model places an emphasis on a holistic description, analysis, and forecasting of the development of competencies and business models within the context of sustainable economics. The four related dimensions of performance, action, learning, and competence designate the structures and processes of motivating, including, and enabling employees to participate in and help form companies' sustainability strategies.

The structure of the reference model displays two perspectives that need to be connected to one another, and that on the one hand represent the company as a social system and on the other hand represent the competencies of system members (see in the following Schlömer, 2009, p. 33 ff.; 2010, p. 6 f.). Connecting these two perspectives is achieved in the model on two levels (see Figure 1): The result level displays correlations between sustainability efforts of social systems (here, the company) and the competencies of system members (here, the employees). So on the result level, the model shows which of the company's economic sustainability goals as performances correlate to which of the employee-related competencies. Also in the figure, the promotion of individual competencies and their constructive connection to performance-related action are displayed on an action and learning level. With the professional and work action in mind, it can be described which learning concepts include and enable the members of social systems to make individual contributions to sustainable economics in a company's performance.

On these two levels, the organizational and individually-related perspectives connect with one another on the basis of the foundational competency-theoretical and systemic-constructivist assumptions. Because these two levels have a reciprocating relationship to one another, they also need to be interconnected: The result level provides the action level with system-relevant goals and meaning criteria, and in doing so makes clear to system members how to direct their learning processes, action, and communication. The result level also shows which competencies should be promoted as training goals, and the company sustainability efforts and performances 
they relate to. The action level even goes as far as to serve as a kind of update for the result level in how system services of sustainable economics and competencies are promoted, with existing ones being developed even further.

The connection of the perspectives and levels is differentiated in the reference model by the four dimensions: the performances for sustainable economics (performance dimension) which represent the organizational performance of a social system, and the competencies of the employees as the individual potential of a social system (competence dimension), are connected in the reference model via the action and learning level, i.e. via a social-theoretical analysis of the fields of professional action (action dimension) and a constructivist theory of professional learning (learning dimension).

\subsection{Operationalizing the Reference Model in Research and Development Projects}

When applying the four dimensions to a social system of "company," a system-specific clarification is possible regarding the characteristics found on the result level of the reference model. The model concepts in turn can be integrated as a program line into the system levels of occupational training. This includes everything from the professional and work cultures of company, inter-company, and school-based training centers; to the pedagogical professionalization of teachers at vocational schools; to company trainers, coaches, and those in charge of advanced training; all the way to the didactics of professional fields and education.

The recent research and development projects at the University of Oldenburg's department of professional and economic education apply exactly these concepts of occupational training for sustainable development models. A project sponsored by the European Social Fund (October 2006-December 2007) Nachhaltigkeit in der Fortbildung von Ausbilder(inne)n und ausbildenden Fachkräften in der Tourismuswirtschaft (NAFAUMUS), (Sustainability in the Advanced Training of Professional Trainers in the Tourism Economy) had as a key concept the idea of interconnecting the development of business models for sustainable economics in small and medium enterprises (SMEs) on the one hand and the individual competency development of trainees on the other (Kehl, Rebmann \& Schlömer, 2008). The company-operational learning environments generated in the project instruct the training personnel in the hotel and restaurant industry, local tourism resorts, and at event planners how the medium of occupational training can be applied to achieve not only a socio-cultural, ecologically friendly tourism as a business model, but an effective design field in professional learning as well.

Interconnecting organizational and individual learning processes for sustainable economics is also a central element of vocational schools, most notably when considering the issues of future energy supply and consumption (Porath, Rebmann \& Schlömer, 2009; Schlömer, 2013a). With this in mind, the University of Oldenburg's joint project Bildung für eine nachhaltige Energieversorgung und Energienutzung (Education for Sustainable Energy Supply and Usage) sponsored by the Lower Saxony Future and Innovation Foundation Fund from November of 2008 to October of 2011 pursued the goal of anchoring as broadly as possible learning content and competencies into lessons, school programs, and core curricula with a focus on the topic of how the new energy economy will be achieved. A modular training program held at the university saw instructors from vocational schools motivated and qualified to tackle the lesson plans and school-organizational integration of issues concerning sustainable development with a special focus on the new energy economy (Bloemen, Porath \& Rebmann, 2012).

Together with the Institute for Ecological Economy Research (IÖW), the department of professional and economic education at the University of Oldenburg conducted a study commissioned by the Dessau office of the German Environmental Protection Agency from November of 2009 to October of 2010 to determine the job potential, educational structures, and requirements in environmental lead markets for energy generation, energy efficiency, raw material and material efficiency, sustainable water management, sustainable mobility, and recycling management (Mohaupt et al., 2011). The work at the University of Oldenburg now also sees the didactical operationalization of professional action and competency development for sustainable economics, with a notable example being the didactics of sustainable businesses started in schools by the students themselves (Schlömer, 2013b).

The extensive experience gathered from these developmental projects and research was incorporated into the conception for the Oldenburg model test of the advanced training to become a renewable energies/energy efficiency specialist. This project and its goals of conceptual development on the one hand and theory-based modelling on the other required a well-developed research and project design, which will be described in the following. The Oldenburg reference model-oriented test results will then be presented. 


\section{Project and Research Designs}

A variety of requirements and goals were included in the model test. In terms of the concept-development approach, a model that could actually be transferred over for use in advanced training was to be developed that successfully achieved the rollout from the test phase of the project into the actual structures of professional advanced training. And the advanced training was in fact incorporated during the project itself into the regular course offerings of the project partner BFE. The successful conclusion of its pilot phase saw it continue to enjoy strong interest among students (and which continues to be the case). Talks have been held with institutions in other regions who are also interested in including this training into their programs (some modifications will have to be made to it to meet the specific educational and work-related needs and requirements of the respective regions). Even before the model test began, project participants expressed their desire to produce an advanced training having a both a generalist and interdisciplinary competency profile and curriculum. This appeared essential, most notably in light of the formation of the market, energy, and information technology interfaces occurring in current energy value chains.

In addition, it was clear at the start of the model test that the advanced training curriculum to become a renewable energies/energy efficiency specialist would experience a relatively quick process of becoming outdated due to continually new technical advances. In other words: the training should have a modular structure, and be kept flexible enough to allow changes and "updates" to individual modules. Regulatory standards would also need to be created to not only ensure the quality of the advanced training, but also to offer it in a way that formally recognizes and advances the professional and educational backgrounds of the participants even further. This is why the training was placed in the level five categorization (described in the introduction) as defined by the German Chamber of Crafts.

These goals and requirements were incorporated into the research and development design that systematizes and structures the conceptual development, testing, and ultimate implementation and evaluation of the renewable energies/energy efficiency specialist advanced training (see Figure 2). A chronologically effective project structure planning with three working phases was selected to achieve this.

The first working phase addressed theoretical and empirical explorations. Here, a number of thorough empirical surveys were conducted based on the competency-theoretical and systemic-constructivist thinking on competency development and professional action presented in Section 2.2 with the goal of investigating future employment fields and the corresponding competency requirements of trade companies in the context of the transition to the new energy economy. On the one hand, the dimensions in the reference model for the theory-modelling approach towards occupational training for a sustainable development in the energy economy could be differentiated. On the other hand, the empirical study provided an important decision foundation for the conceptual and developmental approach of an advanced training that is empirically founded within the energy economy job market.

With this in mind, the following thematic areas were investigated: changes to value chains, business models, and processes in the transition to the new energy economy and the corresponding changes to the qualitative need for specialists (performance dimension); what professional action and areas of activity will look like in the future energy economy (action dimension); goal-driven training strategies and energy economy-related learning content and goals with the right kinds of training courses being offered (learning dimension); and the required professional competencies and backgrounds needed in the new energy economy (competence dimension).

These topics were first investigated using a qualitative interview study (semi-structured, guided; from February to March of 2011) with 22 experts (see in the following Feldkamp et al., in press). Most of the interview participants came from industry (5), trades (5), energy providers and services (3), and planning/engineering offices (1). Five additional experts were interviewed from training centers working in the field of energy, as well as three chamber members who work in education and training. This wide sampling of interview partners and the breadth of findings in the guided interviews provided strong overall insight into the employment and activities of the entire value chain found within future energy production and usage industries. The interview results obtained from the structured content analyses allowed a description and understanding of business models, professional fields of action, industry-specific course offerings, and competency profiles as dimensions of occupational training for a sustainable energy economy (theory-modelling approach). These were then transferred into a first draft of an advanced training outline for renewable energies/energy efficiency specialists.

This draft was then further refined via the quantitative online company survey from May to July of 2011. 7,600 companies were contacted via e-mail to generate a random sample. This sample kept in mind the selected focal points of the model test, including both the industries (within the trades) as well as the regions (Lower Saxony 
and Bremen), and was reflected in the surveys returned by the companies (rate: $6.04 \%$ ) who elected to participate $(n=459) .80 .61 \%$ of the companies operated in trade businesses, with the rest coming from the service sector $(6.10 \%)$, energy supply $(5.66 \%)$, and industry $(3.4 \%)$, with a remaining $4.14 \%$ coming from miscellaneous fields. A partial random sample of trade enterprises $(\mathrm{n}=370)$ can be broken down even further into the electrical trade $(38.38 \%)$, hot water and gas $(29.73 \%)$, heating contractors $(29.46 \%)$, heating and air conditioning (19.46\%), plumbing (13.78\%), and the chimney sweep trade $(12.70 \%)$ (multiple answers were possible). When looking at where these companies are geographically, the majority of them are in Lower Saxony (37.25\%), followed by Bavaria (9.8\%), North Rhine-Westphalia (9.15\%), Baden-Württemberg (7.19\%), Rhineland-Palatinate (6.54\%), and Bremen (5.23\%). The remaining companies (24.84\%) are located in the other ten German states.

In the company survey, the following aspects were determined via quantitative evaluation as a means to further refine the advanced training draft (for more, see Feldkamp et al., in press):

- The characteristics of energy economy business models and their market segments, value chains, and cooperations with other trades;

- The area(s) of activity and typical tasks of specialists operating in the energy industry value chain;

- The employment opportunities and demand for non-academic occupational advanced training;

- What the companies believe are necessary training content and competency goals.

In the second working phase, the qualitative and quantitative data were applied as a foundation to conceptualize, develop, and evaluate the advanced training to become a renewable energies/energy efficiency specialist. In cooperation with the BFE and the Oldenburg Chamber of Crafts, exam regulations in accordance with $\S 42 \mathrm{a}$ of the German trade and crafts code were established, upon which a modular curriculum with a total of 412 hours was based. This includes both mandatory as well as elective educational modules (see Section 4.3).

The advanced training itself included a comprehensive evaluation concept featuring both a process and product evaluation. The goal here was determining the training's effectiveness and acceptance by those actually partaking in it, which would allow for any necessary modifications to be made that would help promote and improve the training being offered. To obtain individual evaluation criteria, participants were asked about the expectations they had from the training at its start. In combination with standardized criteria (regarding didactic-methodical quality, instructor professionalism, and the successful combination of theory and practice), these individual criteria formed the foundation for evaluating the individual modules by the participants. The course instructors also performed their own evaluations in accordance with standardized criteria. For a final evaluation step, once all of the advanced training modules had been completed, the entire advanced training process (including the foundational developmental process) was reflected upon as part of a product evaluation.

In the third working phase, the advanced training concept was operationalized into a course offering and tested over an eleven-month period. The results of the product and process evaluations obtained during this test phase led to a conceptual and content modification of the training. Here, expanded self-learning material was integrated into the concept, offering participants essential, as-needed information on energy technology. E-learning elements were also re-worked (chatroom functions and video conferences). May 2013 saw a continuation of the advanced training with a second regular series of courses kicking off at the BFE with 19 participants. And following this, the training concept was adapted to the needs of partners outside the Oldenburg region, promoting its nationwide continuation.

A steering group for quality management was in place for the entire developmental, implementation, and evaluation processes, continually consulting the project and its involved actors. This group included project representatives from the University of Oldenburg as well as external stakeholders from all relevant fields (those participating in the model test, educational providers, chambers, SMEs, and large enterprises). The early involvement of these stakeholders allowed the project to include all of their viewpoints and requirements as the curriculum was developed.

The following description of the project's results is based upon the four dimensions of the reference model for professional action and competencies in sustainable economics introduced in Section 2.2. This allows the findings of the three project phases to be systematically cohered together in a fashion that permits an access to their content for future model tests and research work on occupational training for sustainable development. 


\section{Model Test Results}

\subsection{Business Performance Fields in a Decentralized Energy Economy}

The data gathered from the empirical surveys in the first working phase allowed insight into the characteristics of the business models, particularly those of trade businesses who operate within the new energy economy. A business model describes how a company runs its business and how it performs in terms of the following competencies and key issues (Müller-Stewens \& Lechner, 2011; Oehlrich, 2010):

- Promised value: What value does the company provide, particularly to its customers and stakeholders?

- Value architecture: What company processes is the company activity included in, and with which partners?

- Earnings model: How is value achieved?

In terms of value, typical business models of companies working in the new energy economy offer their customers holistic, mostly all-inclusive solutions for regenerative energy production, efficiency in use, intelligent distribution, and energy storage (see in the following Rebmann \& Schlömer, 2013, p. 356 f.). With these, knowledge-intensive services are of key importance for both the energy providers' business models and, most of all, for trade businesses as "builders of the new energy economy." Here, energy providers will develop from mere producers of electricity to energy consultancy enterprises. Providers will include their customers into the energy supply network (for energy storage as well), letting them know exactly how they can most efficiently use energy as they promote intelligent technical systems with their corresponding prices. This consultation element is already being pointed out by trade businesses as a good idea that will extend well beyond their own four walls to deliver the best energy solutions available.

Value requires a process architecture where companies currently operating in the new energy economy get themselves involved in increasingly complex future projects that see energy efficiency and usage systematically operating together with energy production. The example of modernizing office buildings to make them more energy efficient makes this clear with its goal of minimizing wasted electricity via better insulation and the integration of ventilation systems with heat recovery; energy production facilities (solar heat, geothermal, in-house power stations, etc.) integrated into the building itself; and the intelligent coordination of individual electrical units (via e.g. smart metering technologies). The future could possibly see goals of a more integrative, environmentally friendly mobility for example by increased usage of electric car fleets, and surplus energy being consumed and/or stored by buildings and electricity networks. From an overall perspective, this will require business models to be strongly connected to neighboring/associated operations and service partners.

The high importance placed on this kind of cooperation was reflected in the model test's company survey investigating the cooperations of the trade businesses $(n=323)$ in terms of economic importance and its characteristics. The general importance of cooperation (independent of the new energy economy) was answered as follows: $89.75 \%$ of the companies consider a close cooperation when it comes to working on contracts as at least pretty important ("important": $69.57 \%$ and "pretty important": $20.18 \%$ ). Over half of the companies $(54.18 \%)$ see participation together in a project as an "important" $(28.79 \%)$ or "pretty important" $(25.39 \%)$ reason to cooperate. Nearly half $(47.69 \%)$ participate in cooperations to "develop new processes, applications, or services" (important: $21.99 \%$; pretty important: $25.70 \%$ ).

The following picture emerges in terms of the primary partner companies of the trade businesses. The electrical trade is their most important cooperation partner. From the viewpoint of electrical trade companies $(n=142)$ themselves, cooperation with other companies in the electrical trade $(35.92 \%)$ is the most important. One reason for this is (among other things) the strong degree of specialization of these companies, e.g. when it comes to modern lighting engineering, fire protection, energy efficiency, storage, etc. A comparably high level of importance for electrical trade companies is found with the cooperation with heating engineering $(28.87 \%)$ and roofing companies (23.24\%). Cooperations with other trades are important for literally all of the hot water and gas installer companies $(\mathrm{n}=110)$, primarily with the electrical trade $(49.09 \%)$, roofers $(39.09 \%)$, and masonry and concrete companies $(33.64 \%)$. Cooperations are typical for heating contractors as well, with cooperations with the electrical trade (48.62\%), roofers (39.45\%), and masonry and concrete companies (29.36\%).

An important thing to keep in mind is that companies will only be able to form effective business models for the future energy economy as part of these kinds of cooperations that span different industries and trades. This makes the interaction patterns found in social systems essential as arenas of company action.

\subsection{Professional Action: Lifting Boundaries among Companies Operating in the Energy Economy}

The first key feature of social systems is their synreferentiality. This means that members of social systems agree 
upon common ideas and meanings that form a basis of their actions. Here it needs to be asked: What is the impact of the new energy economy on the everyday business of those who work in the companies bringing about its change?

In its initial empirical studies, and most notably in the evaluation of the training's test phase, the model test showed that the new energy economy will in its early stages bring with it a high level of uncertainty and difficulty in predicting what direction(s) it will take when it comes to future professional action. One solution in dealing with this mentioned by those in the interview study, as well as in the company survey, is a "boundary free" professional action. The model test showed that the trade business has a multifaceted everyday work life that is difficult to predict. Here, typical professional action such as planning energy concepts for private households can no longer just be based upon technical criteria; social-cultural and economic factors now also play an important role. This is clearly seen in the economic evaluation of future energy concepts: Not only do their technological factors have to be determined, but what will their social and environmental goals and impacts be? For example, most people are in favor of the new energy economy, although just about none of them want the power cables or biogas plants next door, or even the shadows cast upon their homes by wind turbines. This creates dilemmas that ultimately must be addressed by the professional and employment world. Those who are implementing local, sustainable steps forward in the new energy economy on a small scale will ultimately be required to find holistic solutions on a large one.

A second key feature of social systems are their components, i.e. their individuals as acting system members. The question from this that emerges is: What opportunities and degree of freedom do the advanced training participants have in helping form the new energy economy?

In the test phase and second run of the BFE advanced training, it was seen that participants as (up-and-coming) specialists are in fact able to play a role in forming the business and employment processes of the new energy economy thanks to their existing jobs in middle- or operative management and their work here that contains a certain amount of freedom. They also understand their role as promoters of sustainability: As they develop their technical-methodical expertise even further for application in the new energy economy with the desire to use it in their professional lives, they are basically forming the energy future as we speak.

New energy economy projects feature high levels of content- and knowledge-based complexity. And the experts surveyed believe that the process- and formation-related spectrum of tasks and requirements found in the business and work processes in this new economy will also expand. So when it comes to completing contracts together with other companies, work systems (most notably in trade businesses) will increasingly see a transition from a work-related company organization to one that encompasses and involves several departments. For everyday trade business, this will mean a shift away from specialized and/or domain-based thinking in companies towards more generalized professional action that involves a number of departments, trades, and companies. For a successful, holistic implementation of the new energy economy, trade businesses will have to (1) be able to effectively inform and consult internal and external customers regarding the use of renewable energy technologies and energy efficiency measures, (2) plan and design both marketing and technical processes (e.g. for electrical units and energy efficiency measures), (3) implement and monitor concrete measures, and (4) market a wide range of concepts for the energy economy, find new areas of business, and obtain new projects. The action and task bundles mentioned in the interviews are reflected in these four general areas of action.

These fields of action can be observed more closely via the organization of social systems (third feature). If social systems actually emerge from trade businesses and cooperations, they will create stable, strong patterns for interaction that to a great extent stand autonomously against behavioral changes of individual members (Klemisch, Schlömer \& Tenfelde, 2008). So the question is: Which interaction patters will be typical for companies, professions, and employment in the future energy economy?

In line with the results of the model test, the advanced training participants now face the challenge of stepping out of their technically trade-specific domains to expand their professional action as comprehensively as possible, particularly when it comes to process, market, and customer orientation. To put it another way, they will have to be able to present complex professional and technical issues within their value chains in a simple, understandable way to customers, stakeholders, and service partners. These communication requirements also become formatively important when different trades have to be coordinated, when new business opportunities are sought for the company, and when increasingly complex work processes need to be structured. Characteristic of this array of tasks is the systematization of the correlations between renewable energy technologies, energy storage, and energy efficiency measures as well as the coordination and holistic management of energy projects among existing uncertainties (technical feasibility, user acceptance, speed of innovation, etc.) in the everyday business 
of the new energy economy. With this being the case, technicians will e.g. be increasingly involved in the comprehensive consultation and planning processes of building contractors (Rebmann, Schlömer \& Schreiber, 2011, p. 13).

\subsection{Advanced Training Course Content}

The multiple action and communication interfaces of the new energy economy became a key element of the renewable energies/energy efficiency specialist advanced training course content, as it effectively implemented the qualitative specialist requirements determined in the foundational study. Instead of a domain-specific, relatively narrow qualification profile, the advanced training concept promotes a professional, across-the-board thinking and action within networked work processes on the part of specialists. It's exactly what's needed in the new energy economy (see Figure 3). The high importance of interface competence (which was determined as one of the study's results) is reflected in the project-oriented design of the advanced training, and the curriculum developed for it has features of both sales/energy economics and energy technology.

The training curriculum of 412 total hours has mandatory modules with comprehensive commercial content discussing among other things the energy economy, energy law, project management instruments, and energy finance. Additional obligatory modules examine energy efficiency from a wide, technical and operational perspective while looking at energy storage, e-mobility, construction physics, lighting engineering, and even $\mathrm{CO}_{2}$ audits. All technologies found in renewable energies are also included in the curriculum. This is complemented by modules on key competencies in the areas of methodical foundations and presentation techniques, as well as electrical engineering, and plumbing and heating. The theoretical and practical learning contents are comprehensively brought together in a final module. And to provide the training participants with further insight into their operational requirements and individual interests, elective modules are offered that take a look at the individual forms of renewable energy.

The modules are didactically action-oriented, and stringently aimed at the actual workday activities of the participants. The practical part of the training is complemented by project work in the field of building restoration to improve energy efficiency, which is done by the participants both conceptually as well as practically. The exam at the Oldenburg Chamber of Crafts is also action-oriented. Here, test candidates plan, conduct, and evaluate a project from their own work experience.

\subsection{Renewable Energies/Energy Efficiency Specialist Competencies}

This advanced training aims at the promotion of a very comprehensive professional action competency needed for the new energy economy (Feldkamp et al., 2012, p. 115 f.). Here, two levels need to be discerned (see Figure 4). On an interdisciplinary competence level, key competencies are promoted as "learn how to learn" abilities. These are not related to any specific professional activity, but are instead useful in overcoming and acclimating to any unforeseeable changes in professional requirements that might emerge at some point (Tenfelde \& Schlömer, 2012). Based on the expert interviews, when it comes to professional activity in the changing energy economy, employees will need competencies in creating and achieving the energy industry transformation occurring along the interfaces between industry, individual trades, and service processes. Here, abilities will primarily be needed for successful interdisciplinary planning, management, and communication that span a multitude of different trades and industries. And because of the high level of change and innovation in the energy industry, lifelong self-learning will be mandatory for all specialists working in it.

Additional core competencies can be identified on a professional, domain-specific level for renewable energies/energy efficiency specialists. These include knowledge of energy systems and methodical ability when it comes to energy efficiency; $\mathrm{CO}_{2}$ calculations; building planning and analysis in terms of multidimensional energy-related issues; energy and load management; electricity trade (as an economic reflection of the complex interrelations in the energy network); and issues of future developments in the interaction between energy providers, customers, and storage technologies.

Even more domain-specific are those competencies aimed for in the training that focus on helping to create the new energy economy in terms of technical, commercial, and energy provider aspects. Basic technical knowledge of facilities engineering and management, building restoration to save energy (particularly as it relates to insulation), and building automation is required here. Specific value is placed on knowledge of the effects of technology (e.g. fundamental knowledge of ventilation systems), mechanical engineering, storage technology, fiber optics, and facility calculation (Anlagenberechnung). Along with this mostly domain-specific knowledge, trade knowledge and ability (preferably from more than one trade) are considered necessary, particularly as a means to better harmonize the interfaces between plumbing, heating and air conditioning, and electrical engineering. 
Because technicians will also have to perform their handiwork with their mouths as well, the experts surveyed feel that basic commercial and marketing competencies will also be necessary for them to promote and sell new technologies as well as the energy supply and usage concepts on the markets they operate in. This means a basic mastery of sales and administrative skills on the part of those who originally were trained only to use their hands. Even these technicians will be expected to display knowledge of laws and building codes; create financial plans; conduct quality management (in terms of both operational processes as well as projects); and participate in sales and marketing.

\section{Concept and Theory Modelling: Final Observations}

The model test results can be summarized in accordance with the approaches described at the start of this paper. The concept-development approach offers as its outcome an advanced training to become a renewable energies/energy efficiency specialist that's one-of-a-kind in Germany. It was started with 15 participants and brought to a successful conclusion at the BFE in Oldenburg. A second run of this training began in May of 2013 with 19 participants. Thanks to an effective cooperation with the Oldenburg Chamber of Crafts, this training is regulated by $\S 42 \mathrm{a}$ of the German trade and crafts code. Its exam regulations have been in place since the program's inception on March $22^{\text {nd }}, 2012$, allowing all participants to take a test with the Oldenburg Chamber of Crafts upon completion of the training modules. All participants from the first run of this training passed this exam in April of 2013.

Along with the program's exam regulations, additional services developed within it include the advanced training infrastructure found at the BFE with its professional staff of instructors, an inclusion of this advanced training into its standard course offering, the learning material, and a well-developed curriculum. This training on the one hand makes a foundational contribution in opening up new business opportunities and advancing SMEs in the fields of renewable energies and energy efficiency, while on the other hand supporting the professional outlooks of specialists as they help to form future energy markets.

The model test's theory-modelling approach generates statements on the way occupational training functions to achieve a sustainable development in energy industry domains, deriving consequences for future research as a result. The model test investigated a central issue in qualification and competence research: how to "bridge the gap" between employment and occupational training. Value chains and business models will change with Germany's decision to eliminate all of its nuclear power plants by 2022, along with the establishment of renewable energy technologies, energy efficiency programs, and the formation of intelligent networks. This upheaval will result in a demand for specific qualifications at a pace and intensity that the training system and its course offerings will hardly be able to keep up with (Rebmann \& Schlömer, 2013, p. 356 f.). Some of the complaints found in research on occupational training include an overly rigid, long-term approach to training; job descriptions that simply don't go "deep enough" to meet the real needs of technological change; and too much focus on disciplines instead of industry-specific task structures found in the working world and with the professional profiles of its employees (Euler, 2010, p. 85). The challenge of bridging this gap is made even more difficult with the rapidly-changing nature of job markets such as those found in the energy economy.

The foundational reference model of the model test (see Section 2.2) addresses these challenges in how it differentiates between professional performance within a new energy economy on the one hand and the individual competencies required for it on the other. At the same time, the reference model suggests the regulation of performance and competence via a systemic-constructivistic theoretical approach, with the model test pursuing this theory-based suggestion: The advanced training to become a renewable energies/energy efficiency specialist achieved a practicable regulation between business models and the job market (performance) on the one hand and individual professional backgrounds and training careers (competence) on the other.

In the model test, a competence research paradigm in occupational training for a sustainable development unfolded that sets itself apart from typical work and professional research practice that assumes timeless, objectifiable, and technocratically controllable qualification requirements, competencies, and professions. This is an approach that is nothing less than a hindrance to the interlocking of dynamic business models and professional areas of action with training courses and professional competency backgrounds. The model test presented here recognized competence, profession, and employment as socially emerged constructions that unfold their importance and functions within their respective application contexts. This allows the areas of action of specialists operating in the new energy economy, and the professional backgrounds and competency profiles of those qualified to operate in this field to be analytically investigated and constructively related to one another.

The findings of this model test make clear that a competency development based on the formation of the new energy economy, and that is achieved through occupational training, should have a generalistic-holistic, 
interdisciplinary approach, instead of the specialization in individual sections and domains of the energy economy that has been preferred to date.

\section{References}

Arbeitskreis Deutscher Qualifikationsrahmen. (2013). Deutscher Qualifikationsrahmen für lebenslanges Lernen. Retrieved http://www.deutscherqualifikationsrahmen.de/de?t=/documentManager/sfdoc.file.detail\&fileID=137542720 2575

Bloemen, A., Porath, J., \& Rebmann, K. (2012). Energiebildungskompetenzen für eine nachhaltige Schulkultur. In A. Bloemen, \& J. Porath (Ed.), Dimensionen und Referenzpunkte von Energiebildung in der Berufs- und Wirtschaftspädagogik (pp. 1-42). München: Rainer Hampp.

Bundesministerium für Umwelt, Naturschutz und Reaktorsicherheit (Ed.). (2012). Erneuerbare Energien in Zahlen http://www.erneuerbareenergien.de/fileadmin/Daten_EE/Dokumente_PDFs_/20130114_BMU_EEiZ_Her bst12.pdf

Bundesverband der Deutschen Industrie e.V. (Ed.). (2008). Internet der Energie. IKT für Energiemärkte der Zukunft. Berlin.

Bundesverband Informationswirtschaft, Telekommunikation und neue Medien e. V. \& Fraunhofer-Institut für System- und Innovationsforschung ISI (Ed.). (2012). Gesamtwirtschaftliche Potenziale intelligenter Netze in Deutschland. Langfassung des Endberichts. Retrieved from http://www.eenergy.de/documents /Studie_Intelligente_Netze $\% 282 \% 29 . p d f$

Chomsky, N. (1970). Aspekte der Syntaxtheorie. Frankfurt a. Main: Suhrkamp.

Dyllick, T. (2003). Konzeptionelle Grundlagen unternehmerischer Nachhaltigkeit. In G. Linne, \& M. Schwarz (Ed.), Handbuch Nachhaltige Entwicklung (pp. 235-243). Opladen: Leske \& Burdrich. https://doi.org/10.1007/978-3-663-10272-4_22

Euler, D. (2010). Der flexible Beruf. Zeitschrift für Berufs- und Wirtschaftspädagogik, Beiheft 24, 79-100.

Feldkamp, D., Lüllau, C., Rebmann, K., \& Schlömer, T. (2012). Angebote der beruflich-betrieblichen Fortbildung in der Transformation der Energiewirtschaft. lernen \& lehren, 107, 112-116.

Feldkamp, D., Lüllau, C., Rebmann, K., \& Schlömer, T. (in Druck). Kompetenzbedarfe und Beschäftigungsfelder im Kontext der Energiewende. In Arbeitsgemeinschaft Berufsbildungsforschungsnetzwerk (Ed.), Weiterentwicklung von Berufen - Herausforderungen für die Berufsbildungsforschung (pp. 1-17). Bielefeld: BiBB.

Gillen, J., \& Kaufhold, M. (2005). Kompetenzanalysen. Zeitschrift für Berufs- und Wirtschaftspädagogik, 101, 364-378.

Hejl, P. M. (1996). Konstruktion der sozialen Konstruktion: Grundlinien einer konstruktivistischen Sozialtheorie. In S. J. Schmidt (Ed.), Der Diskurs des radikalen Konstruktivismus (pp. 303-339). Frankfurt a. Main: Suhrkamp.

Kastrup, J., Rebmann, K., Tenfelde, W., \& Weigelt, T. (2006). Endbericht. Umweltkommunikation und Mitarbeiterqualifizierung im Qualifizierungsverbund "Energieversorgung" von kleinen und mittleren Unternehmen. Projektberichte und Materialien zur Berufs- und Wirtschaftspädagogik, 33.

Kehl, V., Rebmann, K., \& Schlömer, T. (2009). Nachhaltigkeit in der Fortbildung betrieblicher Ausbilder/innen und ausbildender Fachkräfte in der Tourismuswirtschaft. München: Rainer Hampp.

Klemisch, H., Schlömer, T., \& Tenfelde, W. (2008). Wie können Kompetenzen und Kompetenzentwicklung für nachhaltiges Wirtschaften ermittelt und beschrieben werden? In I. Bormann, \& de Haan, G. (Ed.), Kompetenzen der Bildung für nachhaltige Entwicklung (pp. 103-122). Wiesbaden: VS Verlag. https://doi.org/10.1007/978-3-531-90832-8_9

Klieme, E., \& Hartig, J. (2007). Kompetenzkonzepte in den Sozialwissenschaften und im erziehungswissenschaftlichen Diskurs. Zeitschrift für Erziehungswissenschaft, Sonderheft(8), 11-32.

Leleux, F. B. (2011). Noir/Illuminati II. In S. Kraus (Ed.), Entrepreneurship - Fallstudien (pp. 17-33). Wiesbaden: VS Verlag. https://doi.org/10.1007/978-3-7091-0761-4_2 
Mohaupt, F., Konrad, W., Kress, M., Rebmann, K., \& Schlömer, T. (2011). Employment effects and needs for vocational training and qualification in the field of energy-saving building refurbishment. Environment, Innovation, Employment, issue 2. Bonn: Bundesumweltamt.

Müller-Stewens, G., \& Lechner, C. (2011). Strategisches Management, issue 4. Stuttgart.

Oehlrich, M. (2010). Betriebswirtschaftslehre, issue 2. München.

Porath, J., Rebmann, K., \& Schlömer, T. (2009). Energiebildung an Berufsbildenden Schulen. EINBLICKE, 24(49), 52-55.

Rebmann, K., \& Schlömer, T. (2010). Lehr-Lernforschung in der Berufsbildung. In K Büchter (Ed.), Enzyklopädie Erziehungswissenschaft Online (pp. 1-35). Weinheim.

Rebmann, K., \& Schlömer, T. (2013). Systemische Regulierung von Beschäftigung und Beruf am Beispiel der Energiewende. In J.-P. Pahl \& V. Herkner (Ed.), Handbuch Berufsforschung (pp. 351-360). Bielefeld.

Rebmann, K., Schlömer, T., \& Schreiber, B. (2011). Tätigkeitsfelder, Kompetenzbedarfe und Bildungsangebote für die energetische Gebäudesanierung. BAG-Report Bau Holz Farbe, 13(2), 10-15.

Rebmann, K., Tenfelde, W., \& Schlömer, T. (2011). Berufs- und Wirtschaftspädagogik, issue 4. Wiesbaden: Gabler. https://doi.org/10.1007/978-3-8349-6375-8

Schaltegger, S., \& Hasenmüller, P. (2006). Nachhaltiges Wirtschaften aus Sicht des "Business Case of Sustainability". In E. Tiemeyer, \& K. Wilbers (Ed.), Berufliche Bildung für nachhaltiges Wirtschaften (pp. 71-86). Bielefeld.

Schlömer, T. (2009). Berufliches Handeln und Kompetenzen für nachhaltiges Wirtschaften. München: Rainer Hampp.

Schlömer, T. (2010). Berufliche Weiterbildung und Geschäftsmodelle des nachhaltigen Wirtschaftens. bwp@, 19, $1-20$.

Schlömer, T. (2013a). Nachhaltige Entwicklung als Zukunftsprogramm für das Qualitätsmanagement an berufsbildenden Schulen. berufsbildung, 67, 3-7.

Schlömer, T. (2013b). “... das rechnet sich!” - Wir bringen unsere Nachhaltige Schülerfirma ins Geschäft! In G. de Haan (Ed.), Handreichung Nachhaltige Schülerfirmen, Gründen - Umsetzen - Gestalten (pp. 1-55). Berlin.

Tenfelde, W., \& Schlömer, T. (2012). Schlüsselqualifikationen. In H. May \& C. Wiepcke (Ed.), Lexikon der ökonomischen Bildung (pp. 538-540). München: Rainer Hampp.

Volkmann, C. K., Tokarski, K. O., \& Ernst, K. (2012). Social Entrepreneurship and Social Business. Wiesbaden: Gabler. https://doi.org/10.1007/978-3-8349-7093-0

Weinert, F. E. (2011). Vergleichende Leistungsmessung in Schulen. In F. E. Weinert (Ed.), Leistungsmessungen in Schulen (pp. 17-31). Weinheim: Beltz.

\section{Copyrights}

Copyright for this article is retained by the author(s), with first publication rights granted to the journal.

This is an open-access article distributed under the terms and conditions of the Creative Commons Attribution license (http://creativecommons.org/licenses/by/4.0/). 